\title{
THE ROLE OF VILLAGE FUNDS IN VILLAGE FINANCIAL INDEPENDENCE (A Case Study in Jombang Regency)
}

\author{
${ }^{*}$ Susanto, Arys Wahyu, ${ }^{2}$ Moh. Khusaini, \& ${ }^{3}$ Badriyah, Nurul \\ ${ }^{*} B K D P P$, Jombang - Indonesia \\ ${ }^{2}$ Faculty of Economics and Business, Universitas Brawijaya, Malang - Indonesia \\ ${ }^{3}$ Faculty of Economics and Business, Universitas Brawijaya, Malang - Indonesia \\ Note: * Indicates corresponding author
}

\begin{tabular}{|c|c|}
\hline ARTICLE DETAILS & ABSTRACT \\
\hline $\begin{array}{l}\text { Article History } \\
\text { Published Online: }\end{array}$ & \multirow{3}{*}{$\begin{array}{l}\text { This study aimed to analyze the factors that affect village original } \\
\text { income as a component of village financial independence and } \\
\text { evaluate the role of village funds for community empowerment in } \\
\text { strengthening the influence of VoE on village original income in } \\
\text { Jombang Regency. This study used the Moderated Regression } \\
\text { analytical method with the Robust Least Square method to test } \\
\text { the cross-sectional data provided by Siskeudes of Jombang } \\
\text { Regency of } 2019 \text {. The analysis results showed that village asset } \\
\text { utilization affects village original income positively and } \\
\text { significantly. Furthermore, it also confirmed the moderating role } \\
\text { of the village fund for community empowerment in strengthening } \\
\text { the influence of Village-owned Enterprise (VoE) on village original } \\
\text { income. These findings indicated that the allocation of village } \\
\text { funds to targeted community cmpowerment activities has } \\
\text { encouraged the role of VoE in increasing village original income. }\end{array}$} \\
\hline $\begin{array}{l}\text { Keywords } \\
\text { Village financial } \\
\text { independence, Community } \\
\text { empowerment; Village } \\
\text { original income; Village } \\
\text { fund; Village-owned } \\
\text { Enterprises }\end{array}$ & \\
\hline $\begin{array}{l}\text { "Corresponding Author } \\
\text { Email: aws4asus@gmail.com }\end{array}$ & \\
\hline
\end{tabular}

\section{Introduction}

Involvement of villages is a key factor to support the success of regional autonomy. The importance of the role of villages has encouraged the Indonesian government to issue Law Number 6 of 2014 as a guideline of Village Funds annual allocation sourced from the central government's budget to support village development. Complying with the Law, from 2015 to 2019, the central government allocated large funds for village development, as seen in Figure 1.

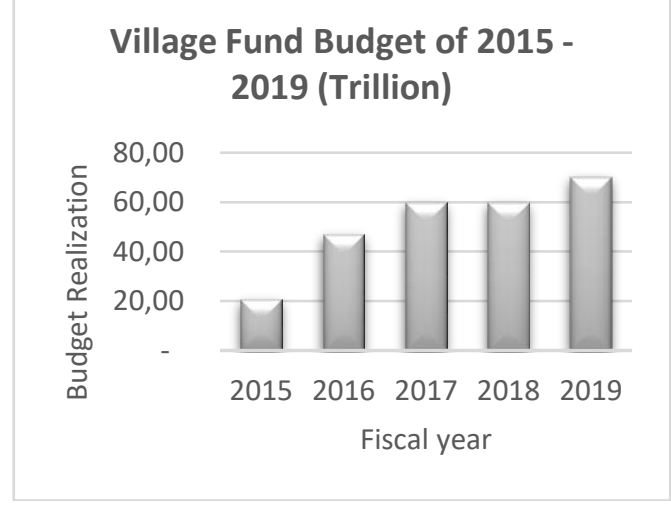

Faculty of Economics and Business,

Universitas Brawijaya
Source: DJPK Kemenkeu Republik Indonesia (2020),

\section{Figure 1 Village Fund Budgeting}

To minimize and prevent villages from being dependent on funds provided by the central government, the government has encouraged village fiscal independence. The funds allocated by the central government are just one of the sources of village income for development. Village governments, for this reason, are encouraged to increase their income by exploring the potential and activities they have, requiring them responsible for identifying and developing their local potential. The development of local potential can increase development, reduce dependence on funds provided by the central government, and increase the independence of villages.

Apart from the importance of independence through increasing village income, the level of village fiscal independence in Indonesia is still far from optimal. For example, the proportions of village original income to central government funds for Jombang District were only $16 \%$ and $13.56 \%$ for 


\section{THE ROLE OF VILLAGE FUNDS IN VILLAGE FINANCIAL INDEPENDENCE (A Case Study in Jombang Regency)}

2018 and 2019, respectively, indicating the existence of some factors influencing the low level of village independence.

Several studies have attempted to identify the factors affecting village original income. Professionalism and optimization of village asset managers were found to be determinants of village original income (Natalia, NLG Sulindawati, \& Atmadja, 2017; Saputra, Jayawarsa, \& Anggiriawan, 2019). The presence or absence of Village-owned Enterprise (VoE) is very crucial in determining village original income (Andari, 2017; Prawitno and Rahmatullah, 2019; Saputra et al., 2019). Also, Atobari (2018) and Dwiningwarni and Amrulloh (2020) found that the use of village funds for community empowerment will affect village original income.

Some of the existing literature focused on three main factors, namely the existence of VoE, VoE management, and community empowerment. These studies have not considered exploring the potential of villages as a source of income to be improved to increase their independence. For this reason, this study aimed to examine the factors that affect village riginal income by considering village potential as one of the determining factors. In this study, two determining factors were used: asset yields and treasury lands as proxies for village potential.

Based on the results of the analysis of the data from the village financial system of 302 villages in the Jombang Regency, this study found that the utilization of village assets had a positive effect on their original income. Furthermore, the amount of the funds the villages owned for community empowerment could increase the influence of the determining factors on their original income.

\section{Literature Review}

\subsection{Decentralization in Indonesia}

Decentralization means devolving responsibility, authority, and resources from the central government to local governments to move the decision-making process to a level closer to the community. On this basis, decentralization aims to make local government programs and activities more effective and efficient (Khusaini, 2018).

The most efficient public services occur if held by the government level closest to the community for the understanding the

Faculty of Economics and Business,

Universitas Brawijaya government of the needs of its community (Khusaini, 2018; Oates, 2006). Villages are the lowest level of government with direct contact with the community. It can be said that a village is a simple form of the existence of the decentralization concept manifested in the form of village autonomy. Therefore, villages are positioned at the forefront of development and improvement of community welfare.

\subsection{Village Government in Village Autonomy}

Based on several definitions of village contained in the Village Law and Law Number 9 of 2015 concerning Regional Government, according to book 7 (seven) of the Ministry of Villages of PDTT, it is emphasized that the sentence "Legal Community Unity" has placed villages as a form of mixed organization consisting of a self-governing community and local self-government. This means that a village is a form of community-based government, in contrast to a regional government which does not contain elements of society but bureaucratic apparatus. Furthermore, the term village is not synonymous with the term village government or the village head. When a village has a local government (local self-government) and a community (self-governing community), its legal entity is formed.

From this understanding, it is implied that a village is a form of community that regulates itself, has the authority to manage and regulate the interests of its community following local social and cultural conditions, which is called village autonomy. With village autonomy, a village government has the authority to regulate and manage the wealth owned by the village to finance the running of government and development in the village following applicable regulations. So, it can be said that the implementation of the village autonomy concept in village government is slightly different from the implementation of the autonomy concept in regional government because village government directly deals with the community and their customs.

\subsection{Village Original Income as a Form of Village Independence}

In terms of financial management, village governments are required to be more 
independent in carrying out their government affairs. Village original income, which is a source of village income, is a form of village independence in managing finances (Saputra, Anggiriawan, Trisnadewi, Kawisana, dan Ekajayanti, 2019) to minimize the village dependence on transfers of funds originating from the central government and local governments.

The Law on Villages also stipulates that apart from the Village Fund which is budgeted from the State Budget, tax revenue sharing, and retribution, as well as the Village Fund Allocation from regional governments, villages are also expected to be able to explore the sources of village original income, to encourage their independence, development acceleration, empowerment of village communities.

According to Saputra et al. (2019), Village original income is a form of efforts made by village governments to support the implementation of village autonomy. Village original income consists of business yields, assets, self-help and participation, cooperation, and others, as implied by Law Number 6 of 2014 Article 72 paragraph 1a.

According to Hardiana (2018), to increase village original income, village governments have broad authority to utilize all sources of village wealth, which includes village treasury lands or village-owned buildings which are one of the village governments' assets as a source of village original income.

Thus, it is necessary to explore supporting potential as a source of village original income, such as the utilization of village wealth sources, village businesses, and others. Besides, the identification of inhibiting factors that affect the sources of village original income is also needed to immediately make improvements so that they become a potential source of village original income.

\subsection{Optimal Management and Utilization of Village Assets to Increase Village Original Income.}

Village Asset Management is regulated in Minister of Home Affairs Regulation Number 1 of 2016 concerning Village Asset Management. Village Assets are items belonging to the Village originating from the original assets of the Village, purchased or

Faculty of Economics and Business,

Universitas Brawijaya obtained from the Village Revenue and Expenditure Budget (APBDesa) or other legal rights acquisition.

Original village assets are in the form of village treasury lands, markets, animal markets, boat moorings, building, fish auctions managed by the village, agricultural product auctions, forests, springs, public baths, and others. According to Saputra et al. (2019), optimizing the use of village-owned assets is to provide benefits to the community and generate income to support an increase in village original income.

The potential of original assets owned by each village is quite diverse due to differences in areas or existing geographical conditions. Village land is a village asset that can be optimally utilized as a source of village income, consisting of tanah bengkok or tanah ganjaran (some villages call it differently) and village treasury lands. Tanah bengkok is generally in the form of agricultural land or productive plantations whose utilization is carried out by the village head and village officials, while the village treasury lands are in the form of buildings, markets, reservoirs, fields, forests, or also partly in the form of productive agricultural land and others. From the existing explanations, the following hypotheses can be formulated:

$\mathrm{H}_{1}$ : The utilization of village assets has a positive and significant effect on village original income.

$\mathrm{H}_{2}$ : Village treasury land area has a positive and significant effect on village original income.

\subsection{The Role of Village-owned Enterprises in Increasing Village Original Income}

The government, through regency, city, and village governments, has developed the economic sector in rural areas through various empowerment programs launched by several ministries. One form of the government's efforts to improve community welfare, through the Ministry of Villages and the Community Empowerment and Village Development Agency to form Village Financial Agencies called Village-owned Enterprises (VoE).

Based on the Village Minister's Regulation on Development of Disadvantaged Areas Number 4 of 2015, the objectives of establishing Village-owned Enterprises are to a) improve the village economy, b) optimize village 


\section{THE ROLE OF VILLAGE FUNDS IN VILLAGE FINANCIAL INDEPENDENCE (A Case Study in Jombang Regency)}

assets to be useful for village welfare, $c$ ) increase community efforts in managing the economic potential of the village, d ) develop plans for inter-village business cooperation and/or with third parties, e) create opportunities and market networks that support public services for citizens, f) create jobs, g) improve community welfare through improved public services and village economic growth and equity, and h) increase community income and village original income.

According to Dewi (2014), the purpose of VoE is to optimize existing village assets, advance the economy and welfare of rural communities, and as a source of village original income. The establishment of $\mathrm{VoE}$ is also an effort to empower the village community to be able to improve their welfare.

It can be said that VoE is a form of optimizing the use of village assets in the form of business units as a form of village community empowerment activities to improve their economy and as a source of village original income. So, it is quite clear that the existence of $\mathrm{VoE}$ is one of the efforts of village governments to increase village original income. From this description, a hypothesis can be formulated as follows:

$\mathrm{H}_{3}$ : The VoE business units have a positive and significant effect on village original income.

\subsection{Village Fund for Village Community Empowerment}

The Village Fund sourced from the State Revenue and Expenditure Budget is a form of commitment from the Government to develop Indonesia from the periphery, among others by increasing development in the village. Based on the Regulation of the Minister of Villages, Development of Disadvantaged Areas, and Transmigration Number 11 of 2019, regarding the Priority for the Use of Village Funds in 2020, the priority of using Village Funds in financing village development programs and community empowerment must provide benefits, one of which is improving the welfare of rural communities by prioritizing 1) financing the implementation of cross-activity programs, 2) sustainable job creation, 3) increasing economic income for poor families, and 4) increasing village original income.
The responsibility for any development program is the existence of a community that is empowered or has the power, strength, or ability. According to Widjajanti (2011), the strength in question can be seen from the physical, material, institutional, economic, cooperation, intellectual strength, and collective commitment aspects in applying the principles of empowerment.

With the priority in the use of the Village Fund according to the applicable provisions where the funding of programs and activities in the field of Village community empowerment aimed at increasing the capacity and capability of the village community is carried out by empowering its potential and resources, it is hoped that the Village can be more independent. According to Dwiningwarni and Amrulloh (2020), the output indicators of the successful management of the Village Fund can be seen from the level of participation of the local village community.

Based on this description, the following hypothesis can be formulated:

$\mathrm{H}_{4}$ : Village Fund for Community Empowerment has a positive and significant effect on village original income.

\section{Research Method}

\subsection{Data and Sample}

The data used in this research were secondary data from data collection and reporting at the Jombang District Community and Village Empowerment Service through the Village Financial System (Siskeudes 2019). The population in this study was all villages in Jombang Regency, amounting to 302. The samples used in this study were the entire population, namely all villages in Jombang Regency.

\subsection{Research Model}

Analysis of the factors that affect Village Owned Income was carried out by estimating the Moderated Regression Analysis regression because this study also analyzed the effect of Village Fund Allocation as a moderating variable on the variable Number of VillageOwned Enterprises to village original income.

The dependent variable used in this study was village original income, while the independent ones used were Village Asset 
Yields, Village Treasury Land Area, Number of VoE, and Village Funds Allocation for Community Empowerment.

The regression model equation used is:

$$
\begin{gathered}
Y_{i=\beta_{0}}+\beta_{1} \text { Asset }_{i}+\beta_{2} V_{T L} \text { Area }_{i}+\beta_{3} V_{\text {VoE }} \\
+\beta_{4} V_{0} E_{i} D_{i}+\varepsilon_{i}
\end{gathered}
$$

Notes:

$$
\begin{array}{ll}
Y_{i} & =\text { Village original income } \\
\text { Asset }_{i} & =\text { Asset Yields } \\
\text { VTL_Area }_{i} & =\text { Village Treasury } \\
& \text { Land area } \\
V o E_{i} & =\text { Number of } \\
& \text { VoE } \\
D D_{i} & =\text { village funds allocation for } \\
\beta_{0} & \text { community empowerment } \\
\beta_{1} \beta_{2} \beta_{3} \beta_{4} & =\text { Intercept } \\
& =\text { Coefficient of each }
\end{array}
$$

\section{Results and Discussion}

Table 1: Descriptive statistics

\begin{tabular}{lrrrr}
\hline \multicolumn{1}{c}{ Variable } & Mean & $\begin{array}{c}\text { Maxim } \\
\text { um }\end{array}$ & $\begin{array}{r}\text { Mini } \\
\text { mum }\end{array}$ & $\begin{array}{c}\text { Std. } \\
\text { Dev. }\end{array}$ \\
\hline Village original & 21623 & 73549 & 4500 & 12108 \\
income & 6408 & 9400 & 000 & 8602 \\
& 19657 & 63000 & 3515 & 11153 \\
Assets Yield & 9308 & 0000 & 000 & 2187 \\
Village Treasury & & 41873 & & 31668 \\
Land Area & 22970 & 7 & 720 & .726 \\
& & & & 0.882 \\
Number of VoE & 1.447 & 6 & 1 & 9359 \\
Village Fund for & 39577 & 37625 & 2200 & 63855 \\
Empowerment & 310 & 0000 & 000 & 295 \\
Number of & & & & \\
Observation & 302 & 302 & 302 & 302 \\
\hline
\end{tabular}

Table 1 shows the descriptive statistics of the 302 study samples. The average village original income 2019 is \pm IDR 216.2 million, with the highest amount of IDR 735,499,400 and the lowest one of IDR 4,500,000. The average asset yield which is the yield of the use of tanah bengkok/ganjaran (the naming in each village is different) is \pm IDR 196.5 million with the highest yield of \pm IDR 630 million and the lowest one of \pm IDR 3.5 million. Meanwhile, the average Village Treasury Land Area (other than tanah bengkok) is $\pm 22,970$ square meters. The average number of Village-owned Enterprises is 1 business unit, with the highest number of 6 business units and the lowest one of 1 business unit in each village. Meanwhile, the average Village Fund Allocation for Community and Village Empowerment activities was IDR 39.5 million with the largest allocation of IDR $376,250,000$ and the smallest allocation was IDR 2,200,000.

\subsection{Model Analysis}

Based on a series of tests to fulfill the classical assumptions, the model used did not meet the requirements in the Normality and Heteroscedasticity tests. To find the cause, the Outlier Test was used to detect the presence of that outlier. According to Hidayatulloh, Yuniarti, dan Wahyuningsih (2015), in linear regression, there is a possibility that outlier data, which is observational data, will appear with an absolute residual value much greater than that of other observational data. According to Montgomery, Peck, dan Vining (2012), an Outlier is an extreme observation result. Its existence will affect the regression model formed. So, it is suggested to use Robust Least Square regression to limit the effect of an outlier on the estimated parameter values. Because of this outlier, the analytical tool used was the Robust Least Square: a non-parametric analysis tool.

According to Ghazali, Yuniarti, dan Hayati (2015), the method with Robust regression is used if there is an outlier in the

\begin{tabular}{|c|c|c|c|}
\hline VARIABLE & $\begin{array}{cc}\text { Coefficient } & \begin{array}{c}\text { Std. } \\
\text { Error }\end{array} \\
\end{array}$ & z-Statistic & Prob. \\
\hline & 0.00206 & & \\
\hline ASSET_YIELD & $\begin{array}{rr}0.970405 & 7 \\
& 0.00162\end{array}$ & 469.4466 & 0.0000 \\
\hline VTL_AREA & $\begin{array}{lr}0.016825 & 2 \\
& 0.00435\end{array}$ & 10.37277 & 0.0000 \\
\hline N_VOE & $\begin{array}{rr}-0.000798 & 2 \\
& 0.00148\end{array}$ & -0.183330 & 0.8545 \\
\hline (DD*N_VOE) & $\begin{array}{rr}0.006643 & 6 \\
& 0.04725\end{array}$ & 4.471034 & 0.0000 \\
\hline$\underline{\mathrm{C}}$ & $\begin{array}{ll}0.388383 & 5 \\
\end{array}$ & 8.218874 & 0.0000 \\
\hline \multicolumn{4}{|c|}{ Robust Statistics } \\
\hline R-squared & $\begin{array}{c}\text { Adjusted } \\
0.819093 \text { squared } \\
\text { Prob(Rn } \\
\text { stat.) }\end{array}$ & i-squared & $\begin{array}{l}0.816656 \\
0.000000\end{array}$ \\
\hline
\end{tabular}
model so that this model is an important tool for analyzing data that is affected by the outlier to get a robust model of the outlier. The Robust model with a Huber weight is one of the most commonly used forms of robust regression estimation (Ghazali et al., 2015).

From the Robust Least Square regression test, the estimated parameter results are presented in Table 2 below:

\section{Table 2. Parameter Estimation Results}




\section{THE ROLE OF VILLAGE FUNDS IN VILLAGE FINANCIAL INDEPENDENCE (A Case Study in Jombang Regency)}

S.E. of regression 0.034359 Sum squared resid 0.350611

From Table 2 for simultaneous testing, the $p$ value obtained is 0.0000 , an assumption that must be met if the $p$-value $<\alpha$. So that the $p$ value $=0.0000<\alpha=0.05$. It can be concluded that simultaneously, all independent variables have a significant effect on the dependent variable. The R-squared value of the output obtained is 0.819093 or $81.9 \%$. This means that the level of variation in the dependent variable Y_VOI can be explained by the independent variables (Asset_Yield, VTL_Area, N_VoE, and DD * N_VoE) of $81.9 \%$; the rest are explained by variables outside the model.

The Standard Error of Regression value is the value of the standard deviation of the dependent variable on the estimated regression line. The smaller the S.E. of Regression, the better the prediction in the regression model. In the output table, the value obtained is 0.034359 : a fairly small value. So, from the existing estimation approach, it can be concluded that the model used is good enough.

Based on the partial significance testing of parameters ( $t$-test) to answer the research hypothesis, it can be seen from Table 2 that only one variable has a $p$-value $>0.005$, namely the number of $\mathrm{VoE}$, which means that it does not significantly influence the dependent variable. Meanwhile, other variables: Asset Yield, VTL Area, and moderating variable of Village Fund with Number of VoE has p-value $<0.005$, which means that it has a significant effect on the dependent variable. It can be concluded that the yields of the utilization of assets have a positive and significant effect on village original income, confirming the hypothesis; the Village Treasury Land Area has a positive and significant effect on village original income according, confirming the hypothesis; and Village Funds Allocation as a moderating variable through $\mathrm{VoE}$ has a positive and significant effect on village original income, confirming the hypothesis. Meanwhile, the number of business units at $\mathrm{VoE}$ has a negative and insignificant effect on village original income and is not in accordance with the hypothesis.

Dari pengujian parameter tersebut dapat dituliskan persamaannya sebagai berikut:

$$
\begin{aligned}
& \text { VOI }=0.3883+0.9704 \text { Asset_Yield }_{i} \\
& +0.0168 \text { VTL_Area }_{i}-0.0007 N_{-} B U M D e s_{i} \\
& +0.0066 D D_{i} N_{-} B U M D e S_{i}
\end{aligned}
$$

\subsection{Discussion}

Village asset yield, which is a form of optimizing the utilization of village assets, confirming the hypothesis, has a positive effect on village original income. This is consistent with the results of a study conducted by Natalia et al. (2017), where the optimization of asset utilization has a positive effect on village original income. These results are also supported by the results of the same studies by Dewi et al. (2017) and Saputra et al. (2019), which also stated that optimizing the use of Village assets affects village original income. Village asset yield is a form of optimizing the utilization of village assets from village treasury lands in the form of tanah bengkok by the Village Head and Village Officials. In general, tanah bengkok in Jombang Regency is the original wealth of the village in the form of productive agricultural land with an area of $88 \%$ of the total village land area. As one of the village assets, the yield of using tanah bengkok is the most dominant source of village original income.

The variable village treasury land area has a significant positive effect on village original income. This positive relationship confirms the initial hypothesis of the study which states that the area of the village treasury land affects the receipt of Village original income. This may imply that the more extensive the Village treasury land is owned, the greater the potential to contribute to village original income. One of the positive actions that can be taken regarding the utilization of village treasury land concerning the economic welfare of villages and village original income is leasing activities between the Village Government and the community. In the land rental theory, lands are natural resources whose supply is limited, thus being scarce and having value. Besides, lands also function as a production factor in economic activity. The concept of leasing can be carried out using the Average Value (per Ha, per $\mathrm{m}^{2}$ ) approach which is the difference between the price of the products resulting from land use and the average cost incurred to purchase inputs in production activities. From this approach, the land area and the rental value formed can be 
linked with each other. Thus, in utilizing village treasury land with a lease system, the area of land affects its rental value, which ultimately affects village original income.

Based on the results of the partial regression estimation, it was found that the variable Number of $\mathrm{VoE}$ has a negative and insignificant relationship with village original income, not following the research hypothesis. It is different from research conducted by Andari (2017), Saputra et al. (2019) that Village-Owned Enterprises play a role in increasing village original income. This finding also contradicted the results of research conducted by Yuniarta and Purnamawati (2020) arguing that the establishment of $\mathrm{VoE}$ has a positive and significant effect on village original income.

The existence of a negative relationship between the number of $\mathrm{VoE}$ and village original income means that the more number of business units in $\mathrm{VoE}$ in one village with constant other variable conditions will potentially reduce village original income in Jombang Regency. This is allegedly due to the poor management of the existing $\mathrm{VoE}$. According to Prawitno and Rahmatullah (2019), inadequate human resources in the management of Village-Owned Enterprises have made the role of VoE less optimal. In the study of human resource management, according to Hakim (2009), from an economic approach, human resources are seen as one of the factors in production activities by economic units. Unlike other production factors, it can be said that human resources are a central factor in economic organization. The ability of human resources in the organization affects organizational achievement. Therefore, managing Village-Owned Enterprises with inadequate human resource capacity will hamper the role of Village-Owned Enterprises in the Village economy.

Village Funds Allocation for Community Empowerment as a moderating variable for Village-Owned Enterprises has a positive and significant effect on village original income. This is in accordance with the research hypothesis at the beginning. This is also supported by qualitative research by Mutolib, Nikmatullah, and Effendi (2019), which stated that the Village Fund program has contributed to the development of VoE so that it can contribute to

Faculty of Economics and Business,

Universitas Brawijaya village original income. Similar results were also stated by Jatmiko (2020) in his research that Village Funds Allocation for the benefits of community economic empowerment through VoE can significantly raise the economy of residents and villages. Of course, this condition is in accordance with what is expected. There is a priority for Village Funds Allocation from the Central Government for the Empowerment of Village Communities with the hope of being able to prosper the village community and can become a source of village income.

In the concept of community empowerment, the purpose of the community empowerment process is to form independent community members so that they can improve the standard of living of their families and optimize their resources. So, in these conditions, Village Funds Allocation for Community Empowerment has achieved the expected targets.

\section{CONCLUSION}

Based on the results of the analysis above, it can be concluded that Village Fund Allocation for Community Empowerment through the existence of Village-Owned Enterprises has a contribution to village original income. As capital in managing Village-Owned Enterprises, good management will certainly provide positive results for the economy of the community and village.

Utilization of village assets in the form of tanah bengkok/ganjaran (each village may have a different term) and village treasury land have a significant contribution to village original income. The use of village assets, which are the village's original wealth, will certainly be a potential source of village income if they can be utilized in accordance with the conditions and potentials they have.

The number of Village-owned Enterprises owned by each village does not contribute to village original income. The low ability of human resources in managing VoE will affect the outcomes of the business itself. The more the number of $\mathrm{VoE}$ business units in one village, without proper management, will become a special burden for village finances. Thus, the formation of a VoE business unit should be adjusted to the potential that exists in each village and should be supported by 


\section{THE ROLE OF VILLAGE FUNDS IN VILLAGE FINANCIAL INDEPENDENCE (A Case Study in Jombang Regency)}

adequate management capabilities in addition to considering the number of business units to be developed.

The implication of this research is the importance of village independence in village financial management. The existence of high village independence will reduce the level of dependence of the village on the central and regional governments in terms of its finances. Exploring a village's potential, optimal utilization of its assets, and the existence of a healthy VoE, supported by Village Fund Allocation that is right on target, will be able to support village original income, to encourage Village independence as a manifestation of the success of Village autonomy policies in Jombang Regency.

This research still had limitations, the results of using regression were of course only a general trend approach based on the data used, and did not reflect the actual conditions for each village. This was due to the different conditions that each village had. Further, more in-depth research still needs to be done to see the actual conditions in each village by adding variables, choosing a more appropriate method, and others.

\section{References}

Andari, I. G. A. R. (2017). Optimalisasi Pengelolaan Pendapatan Asli Desa Untuk Meningkatkan Pembangunan Perekonomian Desa Pada Desa Pejarakan, Kecamatan Gerokgak, Kabupaten Buleleng. JIMAT (Jurnal IImiah Mahasiswa Akuntansi S1), 7(1). https://doi.org/10.23887/jimat.v7i1.9674

Atobari, A. J. (2018). Analisis Pengaruh Sistem Perencanaan Pengelolaan Dana Desa Terhadap Peningkatan Pendapatan Asli Desa. Praja Lamongan Balitbangda Kabupaten Lamongan, I, 19-27.

Dewi, P. E. D. M., Prayudi, M. A., \& Saputra, K. A. K. (2017). Hubungan kualitas pengelolaan aset Desa dan pendapatan asli Desa ( Studi pada Desa-Desa di Kabupaten Buleleng - Bali ). In Seminar Nasional Riset Inovatif, 5(3), 253-260.

Dwiningwarni, S. S., \& Amrulloh, A. Z. (2020). Peranan Pengelolaan Dana Desa Untuk Meningkatkan Pendapatan Masyarakat Di Jombang Jawa Timur. EKUITAS (Jurnal Ekonomi Dan Keuangan), 4(1), 1. https://doi.org/10.24034/j25485024.y2020 .v4.i1.4128
Ghazali, A., Yuniarti, D., \& Hayati, M. N. (2015). Metode Regresi Robust Dengan EstimasiM pada Regresi Linier Berganda (Studi Kasus: Indeks Harga Konsumen Kota Tarakan). Jurnal EKSPONENSIAL Volume 6, Nomor 2, Nopember 2015, 6, 137-142.

Hakim, A. (2009). Dinamika Manajemen Sumber Daya Manusia Dalam Organisasi (Pendekatan Konvensional dan Nilai-Nilai Islami). Semarang: E.F Press Digimedia.

Hidayatulloh, F. P., Yuniarti, D., \& Wahyuningsih, S. (2015). Regresi Robust Dengan Metode Estimasi-S Robust Regression Method To Estimate - S. Eksponensial, 6(2), 163-170.

Jatmiko, U. (2020). Pemberdayaan Ekonomi Berbasis Kearifan Lokal Sebelum dan Sesudah Pengalokasian Dana Desa. Jurnal Manajemen Dan Kewirausahaan, 5(2), 107-121.

Khusaini, M. (2018). Keuangan Daerah (UB Press, ed.). Malang: UB Press.

Montgomery, D. C., Peck, E. A., \& Vining, G. G. (2012). Introduction to Linear Regression Analysis fifht Edition (5th ed., Vol. 7). New York: John Wiley \& Sons, Inc.

Mutolib, A., Nikmatullah, D., \& Effendi, I. (2019). Kontribusi Dana Desa dalam Pembangunan Badan Usaha Milik Desa Di Desa Hanura, Kabupaten Pesawaran, Provinsi Lampung. JSHP: Jurnal Sosial Humaniora Dan Pendidikan, 3(1), 10-19. https://doi.org/10.32487/jshp.v3i1.535

Natalia, Y. S., NLG Sulindawati, E., \& Atmadja, A. T. (2017). Pengaruh Profesionalisme Pengelolaan Aset Desa, Optimalisasi Pemanfaatan Aset Desa, Dan Pemberdayaan Masyarakat Terhadap Pendapatan Asli Desa (Studi Pada Desa Di Kabupaten Tabanan). Akuntansi, 7(1), 4.

Oates, W. E. (2006). On the theory and practice of science. Institute for Federalism \& Intergovernmental Relations, 162(637), 33-43.

https://doi.org/10.3989/arbor.1999.i637.1 680

Prawitno, A., \& Rahmatullah. (2019). Analisis Peranan Badan Usaha Milik Desa ( BUM DESA ) Dalam Peningkatan Pendapatan Asli Desa Di Kabupaten Gowa. Jurnal IImu Sosial Dan IImu Politik, 5(2), 50-60.

Saputra, K. A. K., Anggiriawan, P. B., Trisnadewi, A. A. A. E., Kawisana, P. G. W. P., \& Ekajayanti, L. G. P. S. (2019). Pengelolaan Pendapatan Asli Desa Sebagai Landasan Pembangunan Ekonomi PeDesaan. Ekuitas: Jurnal 


\section{Arys Wahyu Susanto}

Pendidikan Ekonomi, 7(1), 5. https://doi.org/10.23887/ekuitas.v7i1.166 88

Saputra, K. A. K., Jayawarsa, A. A. K., \& Anggiriawan, P. B. (2019). Dukungan Pemerintah Daerah, Optimalisasi Asset Dan Profesionalime Untuk Meningkatkan Pendapatan Asli Daerah ( Pad ). Jurnal
Riset Akuntansi Dan Bisnis Airlangga, 4(1), 607-622.

Yuniarta, G. A., \& Purnamawati, I. G. A. (2020). Apakah Potensi Desa Dan

Kepemimpinan Transformasional Mampu Meningkatkan Pendapatan? Jurnal Akuntansi Multiparadigma, 11(1), 77-88.

https://doi.org/10.21776/ub.jamal.2020.11.1.05 